\title{
Viewpoint \\ Amping up estrogen receptors in breast cancer
} Amy M Fowler and Elaine T Alarid

Department of Oncology, University of Wisconsin-Madison, Madison, WI 53706, USA

Corresponding author: Elaine T Alarid, alarid@oncology.wisc.edu

Published: 16 August 2007

This article is online at http://breast-cancer-research.com/content/9/4/305 (c) 2007 BioMed Central Ltd
Breast Cancer Research 2007, 9:305 (doi:10.1186/bcr1748)

the first to investigate whether a common mechanism of oncogene activation, gene amplification, occurred at the ER $\alpha$ gene locus during tumor progression. Their work is an important scientific contribution that expands upon prior studies demonstrating ESR1 gene amplification in breast cancer cell lines and in some advanced tumors [5-7].

\section{Causes of $E R \alpha$ overexpression in breast cancer}

The pattern of ER $\alpha$ expression in normal breast tissue compared with precancerous and cancerous lesions is strikingly different. In normal breast tissue, ER $\alpha$ expression is restricted to a small proportion of non-proliferating luminal epithelial cells, typically at low to intermediate levels $[8,9]$. However, in more than half of premalignant lesions and carcinomas, this dissociation breaks down and the receptor is detected in proliferating cells, generally at higher levels [8]. Additionally, there is a striking increase in the intracellular amount of ER $\alpha$ protein [10]. A significant unknown in the field of breast cancer is what drives the change in ER $\alpha$ expression and distribution in breast lesions. Holst et al. [4] used fluorescence in situ hybridization (FISH) to probe a tissue microarray containing 2,222 invasive breast cancers and 295 normal, pre-malignant, and pre-invasive samples and found ESR1 gene amplification in 358 samples (21\%) of the 1,739 invasive breast carcinomas with analyzable FISH data. Virtually all (99\%) cases with amplification exhibited correspondingly high ER $\alpha$ protein levels as measured by immunohistochemistry. Characterization of the ESR1 amplicon at 6q25.1 by PCR-based methods found that it was relatively small and did not extend into any other genes. Furthermore, ESR2, which encodes a second ER, ERB, was not amplified. Amplification of other known oncogenes (HER2/neu, MDM2, MYC, EGFR) was detected in invasive cancer samples, although these were found to be independent of ESR1 amplification. Interestingly, ESR1 amplification was observed in proliferative benign breast lesions (36.4\% of papillomas and $8.3 \%$ of usual ductal hyperplasia) and carcinomas in situ (35\% ductal and 33\% lobular) in addition to more advanced

$\mathrm{ER}=$ estrogen receptor; $\mathrm{FISH}=$ fluorescence in situ hybridization. 
tumors [4]. While these studies require independent validation, the data provide evidence that amplification of ER $\alpha$ appears in early lesions and may contribute, in part, to the appearance of high levels of $\mathrm{ER} \alpha$ in breast tumorigenesis.

Gene amplification alone, however, cannot explain all cases involving high $\mathrm{ER} \alpha$ protein levels. Only $54 \%$ of cancers with high ER $\alpha$ expression also had gene amplification [4]. The remaining 46\% showed high ER $\alpha$ expression without gene amplification [4]. This suggests that other mechanisms contribute to high $\mathrm{ER} \alpha$ protein levels, such as altered regulation of ESR1 transcription, mRNA stability, or ER $\alpha$ protein turnover. For example, recent studies have demonstrated that disruption of caveolin-1 and micro-ribonucleic acid 206 can increase $E R \alpha$ levels $[11,12]$. How such upstream factors regulate the $\mathrm{ER} \alpha$ gene and protein is not well understood and needs further attention.

\section{Role of misregulated ER $\alpha$ expression in breast tumorigenesis}

A significant point raised by the finding of ESR 1 amplification in early lesions is whether high levels of ER $\alpha$ expression are a cause or consequence of malignant transformation. Studies of HER2/neu provide a clear example where overexpression of an amplified gene product is oncogenic [13]. Could this also be the case for ER $\alpha$ ? ESR1 gene amplification was identified in several benign proliferative breast lesions, which increase a patient's risk of cancer [14]. Studies have shown that high levels of $E R \alpha$ are present in benign epithelium of women with breast cancer compared to controls and there is an inability to downregulate the receptor in response to estrogen in these cases, supporting a potential role for ER $\alpha$ overexpression in breast cancer risk $[15,16]$. Transgenic mouse models also indicate that overexpression of $\mathrm{ER} \alpha$ is sufficient for the development of ductal hyperplasia, lobular hyperplasia, and ductal carcinoma in situ [17].

How high ER $\alpha$ levels might contribute to tumorigenesis is less understood. The simplest explanation is that the presence of additional receptors supports a more robust response to estrogen. An alternative and intriguing possibility comes from analogy of studies conducted on ErbB2/Her2neu. Proteomic analysis of ErbB2 protein interactions showed that elevated concentrations of ErbB2 lead to promiscuous interactions and promote activation of distinct signaling pathways [18]. In this model, overexpression of the oncoprotein, resulting from amplification or other processes, could lead to an expansion of its regulatory role by permitting protein interactions that activate non-canonical signaling pathways. Similar findings have been reported for $\mathrm{ER} \alpha$ in a breast cancer cell model system of $\mathrm{ER} \alpha$ overexpression in which the mechanism of transactivation and target gene regulation differ when $\mathrm{ER} \alpha$ protein levels are elevated $[19,20]$. These studies of ErbB2 and ER $\alpha$ overexpression raise the interesting scenario that perhaps $E R \alpha$ in normal breast epithelium is maintained at restrictive levels that are necessary to promote differentiation. When the ER $\alpha$ protein concentration increases during tumorigenesis, promiscuous interactions with coregulatory proteins or DNA could lead to the activation of proliferative signaling pathways, which, at normal levels of expression, would be too weak to occur. This scenario would predict that amplification or overexpression of $\mathrm{ER} \alpha$ would be causally related to the high proliferative capacity of ER+ cells. This possibility remains to be tested.

\section{Clinical implications}

Classification of tumors into subtypes helps predict therapeutic responses and patient survival. Categorizing breast tumors as either $\mathrm{ER} \alpha$ positive or negative by immunohistochemistry has proved clinically useful in determining which patients would benefit from endocrine therapy. More recently, microarray analysis has further refined the groupings of breast tumors on the basis of distinct gene expression profiles: basal-like, HER2+/ER-, normal breast-like, luminal A, and luminal $B$ [21]. The latter has clearly shown that the ER positive cohort is not a single group of patients. Both luminal $A$ and $B$ subtypes are $E R+$; however, patients with luminal $B$ tumors have poorer outcomes. The ER+ cohort can also be subdivided into IE and IIE subtypes. The group IIE tumors are similar to subtype B and express more proliferative genes [22]. The same proliferative gene signature was shown by Dai et al. [23] to be a marker of poor outcome in patients with tumors expressing high levels of $\mathrm{ER} \alpha$ for their age. Although it is currently standard practice to offer hormonal therapy to all patients categorized as ER+, these and other studies demonstrate marked heterogeneity within this group in terms of gene expression profiles and patient survival.

Holst et al. [4] analyzed the clinical utility of classifying tumors based on ESR1 amplification. Phenotypes associated with ESR1 amplification included low tumor grade and lack of lymph node metastases, both positive prognostic indicators. Furthermore, tumors with ESR1 amplification were associated with longer survival in patients treated with adjuvant tamoxifen compared with non-ESR1 amplified and ER-negative tumors. However, there was no statistically significant difference in survival for patients with cancers having ESR1 amplification compared to patients with non-ESR1 amplified cancers containing the highest level of ER $\alpha$ protein $(P=0.09)$. Thus, the classification of tumors based on ESR1 amplification does not yield more clinical information than does the current method of tumor characterization based on $\mathrm{ER} \alpha$ protein levels.

While all breast cancers are analyzed for the expression of $\mathrm{ER} \alpha$, steroid receptor status is not routinely measured for benign breast lesions. Depending on the level of suspicion, biopsy-proven benign lesions can either be surgically excised or followed with imaging. One histological group whose management is currently under debate comprises benign papillary lesions, which includes papilloma [24]. Holst et al. [4] showed that ESR1 amplification occurs in 8 of 22 (36\%) 
benign papilloma samples. Furthermore, elevated ER $\alpha$ protein levels have been demonstrated for papillomas and are associated with increased proliferation [25]. Measurement of ESR1 gene amplification or ER $\alpha$ protein levels for papillary lesions may be potentially useful since the presence of amplification or overexpression would argue in favor of surgical excision instead of follow-up imaging.

\section{Conclusion}

Over 100 years have passed since the discovery of the importance of estrogen and, later, $\mathrm{ER} \alpha$ to the growth of breast tumors. Since that time, tremendous advances have been made in our understanding of the molecular mechanisms of ER $\alpha$ activity and in the application of this knowledge to the development of therapies for the prevention and treatment of breast cancer. The recent discovery of ER $\alpha$ amplification in early breast lesions by Holst et al. is an important reminder that, despite our perception that we understand how ER $\alpha$ contributes to pathogenesis, there are still major questions that remain unanswered and breakthroughs to be made. Major clinical dilemmas still revolve around how better to predict response to hormonal therapy and how to fight endocrine resistance. Thus, in 2007, the question, "How does ER contribute to breast cancer?" remains one worth asking.

\section{Competing interests}

The authors declare that they have no competing interests.

\section{Acknowledgements}

We thank the many investigators who have contributed to our understanding of ER $\alpha$ and breast cancer and apologize to those whom we could not include due to limitations in the numbers of references.

\section{References}

1. Beatson GT: On the treatment of inoperable cases of carcinoma of the mamma: suggestions for a new method of treatment with illustrative cases. Lancet 1896, 2:104-107.

2. Cooper AP: The Principles and Practice of Surgery. Volume 1. London; 1836.

3. Jensen EV, Jordan VC: The estrogen receptor: a model for molecular medicine. Clin Cancer Res 2003, 9:1980-1989.

4. Holst F, Stahl PR, Ruiz C, Hellwinkel O, Jehan Z, Wendland M, Lebeau A, Terracciano L, Al-Kuraya K, Janicke F, et al.: Estrogen receptor alpha (ESR1) gene amplification is frequent in breast cancer. Nat Genet 2007, 39:655-660.

5. Nessling M, Richter K, Schwaenen C, Roerig P, Wrobel G, Wessendorf S, Fritz B, Bentz M, Sinn H-P, Radlwimmer B, et al:: Candidate genes in breast cancer revealed by microarraybased comparative genomic hybridization of archived tissue. Cancer Res 2005, 65:439-447.

6. Hicks J, Krasnitz A, Lakshmi B, Navin NE, Riggs M, Leibu E, Esposito D, Alexander J, Troge J, Grubor V, et al.: Novel patterns of genome rearrangement and their association with survival in breast cancer. Genome Res 2006, 16:1465-1479.

7. Schuur ER, Weigel RJ: Monoallelic amplification of estrogen receptor- $\alpha$ expression in breast cancer. Cancer Res 2000, 60: 2598-2601.

8. Clarke RB, Howell A, Potten CS, Anderson E: Dissociation between steroid receptor expression and cell proliferation in the human breast. Cancer Res 1997, 57:4987-4991.

9. Petersen OW, Høyer PE, van Deurs B: Frequency and distribution of estrogen receptor-positive cells in normal, nonlactating human breast tissue. Cancer Res 1987, 47:5748-5751.
10. Fabris G, Marchetti E, Marzola A, Bagni A, Querzoli P, Nenci I: Pathophysiology of estrogen receptors in mammary tissue by monoclonal antibodies. J Steroid Biochem 1987, 27:171-176.

11. Adams BD, Furneaux $H$, White BA: The micro-ribonucleic acid (miRNA) miR-206 targets the human estrogen receptor- $\alpha$ $(E R \alpha)$ and represses ER $\alpha$ messenger RNA and protein expression in breast cancer cell lines. Mol Endocrinol 2007, 21:1132-1147.

12. Li T, Sotgia F, Vuolo MA, Li M, Yang WC, Pestell RG, Sparano JA, Lisanti MP: Caveolin-1 mutations in human breast cancer: functional association with estrogen receptor $\alpha$-positive status. Am J Patho/ 2006, 168:1998-2013.

13. Slamon DJ, Clark GM, Wong SG, Levin WJ, Ullrich A, McGuire WL: Human breast cancer: correlation of relapse and survival with amplification of the HER-2/neu oncogene. Science 1987, 235:177-182.

14. Hartmann LC, Sellers TA, Frost MH, Lingle WL, Degnim AC, Ghosh K, Vierkant RA, Maloney SD, Pankratz VS, Hillman DW, et al.: Benign breast disease and the risk of breast cancer. $N$ Engl J Med 2005, 353:229-237.

15. Khan SA, Rogers MA, Obando JA, Tamsen A: Estrogen receptor expression of benign breast epithelium and its association with breast cancer. Cancer Res 1994, 54:993-997.

16. Khan SA, Sachdeva A, Naim S, Meguid MM, Marx W, Simon H, Halverson JD, Numann PJ: The normal breast epithelium of women with breast cancer displays an aberrant response to estradiol. Cancer Epidemiol Biomarkers Prev 1999, 8:867-872.

17. Frech MS, Halama ED, Tilli MT, Singh B, Gunther EJ, Chodosh LA, Flaws JA, Furth PA: Deregulated estrogen receptor $\alpha$ expression in mammary epithelial cells of transgenic mice results in the development of ductal carcinoma in situ. Cancer Res 2005, 65:681-685.

18. Jones RB, Gordus A, Krall JA, MacBeath G: A quantitative protein interaction network for the ErbB receptors using protein microarrays. Nature 2006, 439:168-174.

19. Jiang X, Ellison SJ, Alarid ET, Shapiro DJ: Interplay between the levels of estrogen and estrogen receptor controls the level of the granzyme inhibitor, proteinase inhibitor 9 and susceptibility to immune surveillance by natural killer cells. Oncogene 2007, 26:4106-4114.

20. Fowler AM, Solodin NM, Valley CC, Alarid ET: Altered target gene regulation controlled by estrogen receptor- $\alpha$ concentration. Mol Endocrinol 2006, 20:291-301.

21. Sørlie T, Perou CM, Tibshirani R, Aas T, Geisler S, Johnsen H, Hastie T, Eisen MB, van de Rijn M, Jeffrey SS, et al.: Gene expression patterns of breast carcinomas distinguish tumor subclasses with clinical implications. Proc Natl Acad Sci USA 2001, 98:10869-10874.

22. Oh DS, Troester MA, Usary J, Hu Z, He X, Fan C, Wu J, Carey LA, Perou CM: Estrogen-regulated genes predict survival in hormone receptor-positive breast cancers. J Clin Oncol 2006, 24:1656-1664.

23. Dai H, van't Veer L, Lamb J, He YD, Mao M, Fine BM, Bernards R, van de Vijver $M$, Deutsch $P$, Sachs $A$, et al.: A cell proliferation signature is a marker of extremely poor outcome in a subpopulation of breast cancer patients. Cancer Res 2005, 65:40594066.

24. Hall FM, Mercado CL, Cangiarella J: Papillary lesions of the breast. Radiology 2007, 243:300-301.

25. Shoker BS, Jarvis C, Clarke RB, Anderson E, Munro C, Davies MPA, Sibson DR, Sloane JP: Abnormal regulation of the oestrogen receptor in benign breast lesions. J Clin Pathol 2000, 53:778-783. 